\title{
Prospects in Cadmium-Contaminated Water Management Using Free-Living Cyanobacteria (Oscillatoria sp.)
}

\author{
Iván Carralero Bon ${ }^{1,2}$, Lucas M. Salvatierra ${ }^{1,2} \mathbb{D}$, Luciana D. Lario ${ }^{1,2}$, Jordi Morató ${ }^{3}$ (D) \\ and Leonardo M. Pérez ${ }^{1,2,3, * \text { D }}$
}

1 Grupo de Biotecnología de Materiales y Medioambiente (Bio\&TecMA), Instituto de Investigaciones en Ingeniería Ambiental, Química y Biotecnología Aplicada (INGEBIO-UCA), Facultad de Química e Ingeniería del Rosario, Pontificia Universidad Católica Argentina (UCA), Av. Pellegrini 3314, Rosario S2002QEO, Argentina; icbon89@gmail.com (I.C.B.); lucas_salvatierra@uca.edu.ar (L.M.S.); lario@rosario-conicet.gov.ar (L.D.L.)

2 National Council for Scientific and Technical Research (CONICET), Ministry of Science, Technology and Productive Innovation, Godoy Cruz 2290, Buenos Aires C1425FQB, Argentina

3 UNESCO Chair on Sustainability, Universitat Politècnica de Catalunya-BarcelonaTech, C/Colom, 1, TR1, ESEIAAT, 08222 Terrassa, Spain; jordi.morato@upc.edu

* Correspondence: perez@inv.rosario-conicet.gov.ar; Tel.: +549-341-421-130

check for updates

Citation: Bon, I.C.; Salvatierra, L.M.; Lario, L.D.; Morató, J.; Pérez, L.M. Prospects in Cadmium-Contaminated Water Management Using Free-Living Cyanobacteria (Oscillatoria sp.). Water 2021, 13, 542. https://doi.org/10.3390/w13040542

\section{Academic Editor: Qilin Wang,}

Dongbo Wang, Yingqun Ma, Jing Sun and Li Gao

Received: 6 February 2021

Accepted: 17 February 2021

Published: 20 February 2021

Publisher's Note: MDPI stays neutral with regard to jurisdictional claims in published maps and institutional affiliations.

Copyright: (c) 2021 by the authors. Licensee MDPI, Basel, Switzerland. This article is an open access article distributed under the terms and conditions of the Creative Commons Attribution (CC BY) license (https:/ / creativecommons.org/licenses/by/ $4.0 /)$.

\begin{abstract}
In this study, the removal of cadmium (Cd) by free-living Oscillatoria sp. was studied. Our results showed that maximal Cd removal efficiency $(\sim 6 \%)$ by the cyanobacterial culture was achieved within 12-24 h in the presence of 5.0 or $25.0 \mathrm{mg} / \mathrm{L}$ of $\mathrm{Cd}$. The mechanisms underlying this phenomenon were explored by elemental analysis and FTIR-ATR spectroscopy. It was found that metal adsorption by negatively charged functional groups in the cyanobacterial biomass was the main mechanism used by Oscillatoria sp. to remove metal from the aqueous medium, followed by $\mathrm{Cd}$ bioaccumulation into living cells. Additionally, Cd-exposed microalgae showed increased oxidative stress (MDA formation), a decreased dehydrogenase activity, a higher amount of soluble carbohydrates and a decreased total carotenoid concentration, as compared to the control cells. These results suggest that Oscillatoria sp. improved its antioxidative defense system under stressful conditions, through carotenoid-mediated ROS quenching and induction of carbohydrate catabolism, in order to counteract the oxidative damage and preserve the photosynthetic machinery and cellular energetics. In fact, no significant reduction in Oscillatoria sp. cell density, total protein amount, and chlorophyll a content was observed after 24-h Cd exposure, even at the highest metal concentration tested (i.e., $25.0 \mathrm{mg} / \mathrm{L}$ ). Hence, the presented results are the first to describe some new insights about the metabolic and physiological behavior of living Oscillatoria sp. during Cd remediation, and open up the possibility of finding an equilibrium that maximizes metal removal performance with an active cyanobacterial metabolism, to achieve a rewarding and sustainable management of industrial metal-polluted wastewater.
\end{abstract}

Keywords: cadmium-polluted water; ecotechnologies; bioremediation; free-living cyanobacteria; Oscillatoria sp.

\section{Introduction}

Heavy metal pollution of fresh-water reservoirs is one of the most relevant environmental issues since toxic metal persistence in water poses a serious risk to both aquatic organisms and human beings [1]. Most metals are waste products of industrial and metallurgical processes and their environmental impact is largely increased due to the continuous release of aqueous effluents containing heavy metals without an appropriate treatment. This malpractice is somewhat frequent in poor and developing countries where sanitary solutions are weak and scarce, and toxic metals are often discharged into natural water sources without adequate handling, and poses a major health risk $[2,3]$. 
In particular, cadmium (Cd) is one of the most toxic metals often linked to human poisoning. Common sources of $\mathrm{Cd}$ include wastes from $\mathrm{Cd}$-based batteries and runoff water from agricultural soils impacted with Cd-containing phosphate fertilizers. In addition, a large amount of $\mathrm{Cd}$ is naturally released into rivers through the weathering of rocks. Cadmium is also used in mining, metallurgical operations, electroplating industries, manufacturing of vinyl plastics, and as a pigment in paint production [4]. Furthermore, $\mathrm{Cd}$ is present in most foodstuffs, such as cereal products, vegetables, nuts, starchy roots, and meat products [5]. Therefore, Cd exposure is still a global concern.

Although $\mathrm{Cd}$ toxicity is a highly-explored matter, complete control over $\mathrm{Cd}$ pollution is still far from being achieved and cases of $\mathrm{Cd}$ poisoning are still reported. Long-term human exposure to high levels of $\mathrm{Cd}$ induces renal damage associated with kidney and chronic liver dysfunction. In addition, this element is classified as a Group 1 human carcinogen, based on data reporting an increased risk of prostate, lung, endometrium, bladder, and breast cancer, related to $\mathrm{Cd}$ exposure $[4,6]$. Moreover, $\mathrm{Cd}$ is found to be highly toxic to fish and other aquatic organisms $[7,8]$. Thus, $\mathrm{Cd}$ is considered a priority water pollutant from a monitoring perspective by most countries and international organizations. In fact, this element is currently listed by the World Health Organization (WHO) as one of the chemicals of major public concern [9]. According to WHO's recommendation, the $\mathrm{Cd}$ limit in drinking water is $0.005 \mathrm{mg} / \mathrm{L}$. Therefore, the treatment or purification of Cd-polluted water and effluents is an active research area.

Several physicochemical technologies such as chemical flocculation/precipitation, ion exchange, solvent extraction, reverse osmosis, electrochemical deposition, and membrane filtration are usually employed to clean up metal-polluted waters and remove heavy metals from industrial effluents $[10,11]$. However, many of these solutions are technically infeasible, expensive, environmentally hazardous, or far away from the desired performance [12]. In the last decades, the search for cost-effective biotechnologies for the eco-management of metal-containing wastewaters gained a lot of attention $[13,14]$. Besides its eco-friendly spirit, these new biotechniques should be efficient enough to comply with the current legislation demands [12]. In this context, research efforts were made for $\mathrm{Cd}$ removal from aqueous systems based on biosorption techniques. Various biomaterials such as bacteria, fungi, yeasts, algae, and plants were employed to investigate effective Cd-biosorption systems [15-18].

Cyanobacteria are also excellent models for metal bioaccumulation studies. These organisms are the largest and most diverse group of photosynthetic prokaryotes that have the ability to survive in both fresh and marine brackish waters. During evolution, cyanobacteria developed diverse strategies to maintain an equilibrated relation with heavy metals in the surrounding medium [19]. Therefore, these microorganisms are excellent candidates for an efficient elimination of metal ions from polluted environments [20], especially those cyanobacteria that lack commercial value (e.g., for food purposes).

Heavy metal toxicity against cyanobacteria depends on the metal type and concentration, the taxon (i.e., the types of cyanobacteria), and the environmental conditions such as temperature, $\mathrm{pH}$, and light conditions $[7,13,14,19,20]$. Living cells are likely to be more sensitive to metal ions. Therefore, most studies oriented to heavy metals removal from aqueous systems are made using dried, non-living, or pre-treated cyanobacterial biomass $[15,16,20,21]$. However, metabolically-active cyanobacteria can also be used for large-scale production of energy, biofertilizers, secondary metabolites, cosmetics, and medicines [22-24]. Therefore, in removing metal ions from wastewaters, living cyanobacteria could be used as an eco-friendly sustainable practice coupled with biomass production. This entails the additional benefits of increasing the oxygen supply to the treatment system, with the avoidance of anoxic zones, decreasing the $\mathrm{CO}_{2}$ levels, or converting radiant energy into chemical energy for further industrial usage $[23,25,26]$.

In the present study, a non-market, self-flocculating, and cost-effective filamentous cyanobacterium (Oscillatoria sp.) was investigated for Cd elimination from artificiallycontaminated water solutions. The effect of metal concentration on oxidative damage and 
the Cd removal capacity of living cells was explored. In addition, the different uptake mechanisms used for Oscillatoria sp. during Cd removal were also assessed. Finally, the effects of $\mathrm{Cd}$ bioaccumulation on cyanobacterial cell viability, photosynthetic pigment content (i.e., chlorophylls and carotenoids), and carbohydrate and protein biosynthesis were also evaluated.

\section{Materials and Methods}

\subsection{Microorganism and Culture Conditions}

Oscillatoria sp. inoculum was kindly provided by a local producer, through the National Institute of Agricultural Technology (INTA-Rosario, Centro Regional Santa Fe, Argentina). Taxonomic classification was carried out by the Instituto del Alimento (Secretaría de Salud Pública, Municipalidad de Rosario, Argentina), based on the morphological characteristics. Pure microalgae culture $(>90 \%)$ was grown in a modified Zarrouk's medium (pH 7.4) containing $\mathrm{NaHCO}_{3}(16.8 \mathrm{~g} / \mathrm{L}), \mathrm{K}_{2} \mathrm{HPO}_{4}(0.5 \mathrm{~g} / \mathrm{L}), \mathrm{NaNO}_{3}(2.5 \mathrm{~g} / \mathrm{L}), \mathrm{K}_{2} \mathrm{SO}_{4}$ $(1.0 \mathrm{~g} / \mathrm{L}), \mathrm{NaCl}(1.0 \mathrm{~g} / \mathrm{L}), \mathrm{MgSO}_{4}(0.2 \mathrm{~g} / \mathrm{L}), \mathrm{CaCl}_{2}(0.04 \mathrm{~g} / \mathrm{L})$, and $1 \mathrm{~mL}$ of a solution consisting of $\mathrm{H}_{3} \mathrm{BO}_{3}(2.86 \mathrm{~g} / \mathrm{L}), \mathrm{MnCl}_{2}(1.81 \mathrm{~g} / \mathrm{L}), \mathrm{CuSO}_{4}(0.222 \mathrm{~g} / \mathrm{L})$, and $\mathrm{MoO}_{3}(0.015 \mathrm{~g} / \mathrm{L})$. The cells were incubated at $24 \pm 2{ }^{\circ} \mathrm{C}$ in a glass aquarium adapted with air diffusers, and under a cool white fluorescent light intensity of $100 \mu \mathrm{E} \mathrm{m}^{-2} \mathrm{~s}^{-1}$ (Osram Dulux L HE, Munich, Germany) in 12-h light-dark cycles, which is suitable for photosynthesis. Before the experiments, the biomass was harvested by centrifugation at $4000 \mathrm{rpm}$ for $10 \mathrm{~min}$, using a Tyfon II centrifuge (Zelian S.A., Buenos Aires, Argentina). The cell pellets were washed twice with saline solution $(\mathrm{NaCl} 0.9 \mathrm{~g} / \mathrm{L})$ to eliminate trace elements that might potentially interfere with the metal binding properties. At the end of the experimental period $(24 \mathrm{~h})$, the cyanobacterial biomass was treated for further analytical analysis. In order to determine the dry weight of the biomass, $50.00 \mathrm{~mL}$ of culture samples $(n=2)$ were filtered using previously tared filter papers (Whatman ${ }^{\mathrm{TM}}$ Grade 589/3, Maidstone, UK) and oven-dried to a constant weight at $80^{\circ} \mathrm{C}$ for $24 \mathrm{~h}$. An average initial cyanobacterial biomass concentration of $0.58 \pm 0.07 \mathrm{~g}$ (dry weight) was used in all experiments.

\subsection{Stock Solution of $C d$}

Cadmium (Cd) stock solution (10,000 $\mathrm{mg} / \mathrm{L})$ was prepared by dissolving analytical grade $\mathrm{CdCl}_{2}$ (Cicarelli, San Lorenzo, Argentina) in deionized water. The $\mathrm{pH}$ of the stock solution was adjusted to $6.0 \pm 0.2$ with $1 \mathrm{~N} \mathrm{HNO}_{3}$ (Cicarelli, San Lorenzo, Argentina), using an AD1030 digital pH-meter (Adwa, Nușfalău, Romania), in order to avoid $\mathrm{Cd}(\mathrm{OH})_{2}$ precipitation, and then this solution was stored at $4{ }^{\circ} \mathrm{C}$. For calibration purposes, standard solutions of $\mathrm{Cd}(0.30,0.60,1.0,2.0,2.5$, and $3.0 \mathrm{mg} / \mathrm{L})$ were prepared by diluting the stock solution with the necessary volume of acidified water $\left(0.15 \% v / v \mathrm{HNO}_{3}\right.$; Cicarelli, San Lorenzo, Argentina) in glass calibrated containers, as recommended by the Varian AA240FS (Varian Inc., Palo Alto, CA, USA) operational manual. All calibration procedures showed reproducible linear relationships $\left(R^{2}>0.98\right)$.

\subsection{Cd Removal Studies and Elemental Analysis}

The removal of Cd by Oscillatoria sp. was examined by incubating the cells on phosphate buffer (pH 7.4) supplemented with 0.0 (control), 5.0, or $25.0 \mathrm{mgCd} / \mathrm{L}$. Experiments were performed in duplicates with $250 \mathrm{~mL}$ Erlenmeyer flasks containing $150 \mathrm{~mL}$ culture, and were incubated at $24 \pm 2{ }^{\circ} \mathrm{C}$ with dark/light cycles of $12 \mathrm{~h}$, under gentle orbital agitation $(80 \mathrm{rpm})$, to avoid cell sedimentation. Culture samples $(10.00 \mathrm{~mL})$ were withdrawn after $0,4,8,12$, and $24 \mathrm{~h}$, and the biomass was harvested by centrifugation ( $4000 \mathrm{rpm}, 10 \mathrm{~min}$ ). The supernatant was then filtered through a PTFE filter (pore size $=0.45 \mu \mathrm{m}$ ), and residual $\mathrm{Cd}$ concentration was measured by atomic absorption, using a Varian AA240FS spectrophotometer (Varian Inc., Palo Alto, CA, USA). Additionally, the pellet was treated for elemental analysis. In brief, the cyanobacterial biomass was washed with $10.00 \mathrm{~mL}$ of $1.7 \mathrm{mM}$ EDTA solution for $60 \mathrm{~min}$ in an orbital shaker, at $180 \mathrm{rpm}$. Samples from this washing were filtered (pore size $=0.45 \mu \mathrm{m}$ ) and used to quantify the Cd adsorbed on the cyanobacterial 
surface through atomic absorption spectrophotometry [27]. The EDTA-washed biomass was then rinsed with deionized water and treated with $1.0 \mathrm{~mL} 65 \% \mathrm{HNO}_{3}$ analytical grade (Cicarelli, San Lorenzo, Argentina). Subsequently, the samples were heated at $70{ }^{\circ} \mathrm{C}$ in a digestion system, for $3 \mathrm{~h}$. Finally, the samples were diluted with water up to a final volume of $10.00 \mathrm{~mL}$, and then filtered with a pore size of $0.45 \mu \mathrm{m}$; the Cd accumulated in cells was spectrophotometrically quantified. Data were reported as the mean value \pm standard deviation (S.D.) of three replicates $(n=3)$.

\subsection{Metal Removal Kinetics}

Kinetic models are frequently used to describe the reaction order of pollutant elimination in bio-based wastewater treatment systems, since the rates of contaminant removal can provide important information concerning the mechanism and behavior at which biological interactions occur and can be used to guide the system design [28]. In general, the dynamics of such bioprocesses can be properly described by the first-order (1) or second-order (2) reaction models, by applying the following equations:

$$
\begin{aligned}
\ln \mathrm{C}_{t} & =\ln \mathrm{C}_{0}-\mathrm{K}_{1} t \\
\frac{1}{\mathrm{C}_{t}} & =\frac{1}{\mathrm{C}_{0}}+\mathrm{K}_{2} t
\end{aligned}
$$

In this study, $\mathrm{C}_{t}$ is $\mathrm{Cd}$ residual concentration $(\mathrm{mg} / \mathrm{L})$ at time $t(\mathrm{~h}), \mathrm{C}_{0}$ is the initial metal concentration in the sample medium $\left(5.0 \mathrm{mg} / \mathrm{L}\right.$ or $25.0 \mathrm{mg} / \mathrm{L}$ ), $\mathrm{K}_{1}$ represents the first-order reaction rate constant, and $K_{2}$ describes the second-order reaction rate constant [29].

\subsection{FTIR-ATR Analysis}

The spectra of dried Oscillatoria sp. biomass were obtained using an IR Prestige21 Fourier Transform Infrared (FTIR) spectrophotometer (Shimadzu, Tokyo, Japan) in the Attenuated Total Reflectance (ATR) mode, to examine active groups on the cyanobacterial biomass with/without Cd (25.0 mg/L) exposure for $24 \mathrm{~h}$. A total of 20 scans over a recording range of $500-4000 \mathrm{~cm}^{-1}$ were performed at $2 \mathrm{~cm}^{-1}$ resolution [28].

\subsection{Analytical Analysis}

\subsubsection{Microbial Growth}

The cyanobacterial growth after $24 \mathrm{~h}$ of $\mathrm{Cd}$ exposure at the different metal concentrations tested (i.e., $0.0,5.0$, or $25.0 \mathrm{mg} / \mathrm{L}$ ) was assessed turbidimetrically as the optical density of the cultures at $560 \mathrm{~nm}$ (O.D.560) [30], using a UV-Vis Lambda 25 spectrophotometer (Perkin Elmer, Inc., Waltham, MA, USA). The experiments were performed in triplicates $(n=3)$.

\subsubsection{Protein Content}

The protein content was determined as described by [31]. In brief, two-milliliter $(2.0 \mathrm{~mL}$ ) aliquots of culture samples were sonicated for $30 \mathrm{~min}$ in an ultrasonic TB-04 TA water bath (TestLab, Buenos Aires, Argentina). Then, a $0.4 \mathrm{~mL}$ portion of this solution was placed in a test tube and $2.0 \mathrm{~mL}$ of a solution containing $2 \%(w / v) \mathrm{Na}_{2} \mathrm{CO}_{3}$ diluted in $0.1 \mathrm{M}$ $\mathrm{NaOH}, 1 \%(w / v) \mathrm{CuSO}_{4} .5 \mathrm{H}_{2} \mathrm{O}$, and $2 \%(w / v)$ potassium-sodium tartrate (in proportion: 50:0.5:0.5) were added. The resulting mixture was vortexed for $30 \mathrm{~s}$ and incubated in dark for $10 \mathrm{~min}$ at room temperature. Finally, $0.2 \mathrm{~mL}$ of the Folin-Ciocalteau reagent were added to the solution and vortexed for another $30 \mathrm{~s}$. After a $30 \mathrm{~min}$ incubation at room temperature, the absorbance of the sample was measured at $750 \mathrm{~nm}$, using a UV-Vis Lambda 25 spectrophotometer (Perkin Elmer, Inc., Waltham, MA, USA). Absorbance values were converted to protein concentration $(\mathrm{mg} / \mathrm{L})$ using a calibration curve established with bovine serum albumin (BSA; Sigma-Aldrich, Steinheim, Germany). Data were reported as the mean value \pm standard deviation (S.D.) of three replicates $(n=3)$. 


\subsubsection{Lipid Peroxidation (MDA Accumulation)}

Lipid peroxidation was evaluated based on the TBARS (i.e., thiobarbituric acid reactive substances) determination, using a modification of the method described by [32]. In brief, cyanobacterial cells ( $1.0 \mathrm{~mL}$ culture sample) were harvested by centrifugation at $4000 \mathrm{rpm}$ for $10 \mathrm{~min}$, the supernatant was discarded, and the remaining biomass was homogenized with $1.0 \mathrm{~mL}$ of $0.5 \%(w / v)$ thiobarbituric acid solution in $20 \%(w / v)$ trichloroacetic acid, added with $0.1 \mathrm{~mL}$ of $4 \%(w / v)$ BHT. The homogenate was boiled for $45 \mathrm{~min}$ at $100{ }^{\circ} \mathrm{C}$ and centrifuged at 10,000 rpm for $10 \mathrm{~min}$ to collect the supernatant. After being cooled at $4{ }^{\circ} \mathrm{C}$, the absorbance of the resulting solution was recorded at $530 \mathrm{~nm}$, using a UV-Vis Lambda 25 spectrophotometer (Perkin Elmer, Inc., Waltham, MA, USA), and corrected for unspecific turbidity by subtracting the value at $600 \mathrm{~nm}$. Malondialdehyde (MDA) concentration was calculated using an extinction coefficient of $155 \mathrm{mM}^{-1} \mathrm{~cm}^{-1}$ and expressed as $\mu \mathrm{mol}$ $\mathrm{MDA} / \mathrm{mg}$ protein. Data were reported as the mean value \pm standard deviation (S.D.) of three replicates $(n=3)$.

\subsubsection{Dehydrogenase Activity}

A decrease in the number of metabolically active cells correlated with a decrease in overall activity of the dehydrogenases responsible for conversion of 2,3,5-triphenyltetrazolium chloride (TTC) to red insoluble 1,3,5-triphenylformazan, a compound that could be spectrophotometrically determined at $485 \mathrm{~nm}$ [33]. Therefore, this colorimetric assay was used to evaluate cyanobacterial viability after $\mathrm{Cd}$ exposure. In brief, $10.00 \mathrm{~mL}$ culture samples

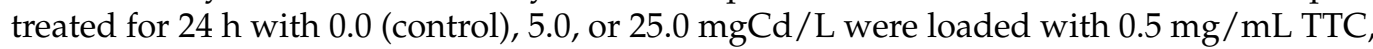
and incubated for $1 \mathrm{~h}\left(37^{\circ} \mathrm{C}, 130 \mathrm{rpm}\right)$ in a shaking bath (SHZ-88, Arcano, Shanghai, China). Then, cells were harvested by centrifugation $(4000 \mathrm{rpm}, 10 \mathrm{~min})$ and the product of the hydrolytic reaction (i.e., formazan) was extracted in $1.0 \mathrm{~mL}$ of $80 \%$ acetone. After centrifugation $(10,000 \mathrm{rpm}, 10 \mathrm{~min})$, formazan was determined by measuring the absorbance of the supernatant at $485 \mathrm{~nm}$, using a UV-Vis Lambda 25 spectrophotometer (Perkin Elmer, Inc., Waltham, MA, USA). The experiments were performed in triplicate $(n=3)$.

\subsubsection{Physiological Parameters}

Quantification of Photosynthetic Pigments

Chlorophyll- $a($ chl- $a$ ) and total carotenoids were obtained by methanolic extraction and quantified by UV-Vis spectrophotometry according to the methods described in [34]. In brief, a $2.0 \mathrm{~mL}$ culture was collected by centrifugation at $4000 \mathrm{rpm}$ for $10 \mathrm{~min}$. After discarding the supernatant, $2.0 \mathrm{~mL}$ of absolute methanol (Merck, Darmstadt, Germany) were added to the cells, followed by vortex agitation. The sample was then kept in the dark at $4{ }^{\circ} \mathrm{C}$ for $24 \mathrm{~h}$, before centrifugation $(10,000 \mathrm{rpm}, 10 \mathrm{~min})$. The absorbance of the supernatant was measured at $470 \mathrm{~nm}$ and $665 \mathrm{~nm}$. The contents of chl-a and total carotenoids were estimated by the following equations:

$$
\begin{gathered}
\text { chl- } a(\mu \mathrm{g} / \mathrm{mL})=13.43\left(\mathrm{~A}_{665}\right) v / b \mathrm{~V} \\
\text { carotenoids } \left.(\mu \mathrm{g} / \mathrm{mL})=4.4\left(\mathrm{~A}_{470}\right) 10\right) / b \mathrm{~V}
\end{gathered}
$$

where $A_{665}$ and $A_{470}$ are the absorbance values at $665 \mathrm{~nm}$ and $470 \mathrm{~nm}$, respectively, against a blank of the solvent used (i.e., methanol); $v$ means the volume of solvent used (mL), $b$ is the spectrophotometric cell length $(1 \mathrm{~cm})$, and $V$ is the sample volume $(\mathrm{mL})$. The concentrations of the photosynthetic pigments were expressed as $\mu \mathrm{g} / \mathrm{mg}$ protein. Data were reported as the mean value \pm standard deviation (S.D.) of three replicates $(n=3)$.

\subsubsection{Carbohydrate Determination}

Carbohydrates were quantified according to the method described by [35]. In short, $2.0 \mathrm{~mL}$ of each Cd-treated sample at the end of the assay $(24 \mathrm{~h})$ were taken in separate test tubes, and the cells were pelleted at $4000 \mathrm{rpm}$ for $10 \mathrm{~min}$. The cell biomass was then mixed with $2.0 \mathrm{~mL}$ of $80 \%(v / v)$ methanol and heated at $70{ }^{\circ} \mathrm{C}$ for $30 \mathrm{~min}$. After being 
cooled, $1.0 \mathrm{~mL}$ of the extract was mixed with $1.0 \mathrm{~mL}$ of $5 \%(v / v)$ phenol (Sigma-Aldrich, St. Louis, MO, USA), and $5.0 \mathrm{~mL}$ of $95 \%(v / v) \mathrm{H}_{2} \mathrm{SO}_{4}$ (Cicarelli, San Lorenzo, Argentina). Later, the mixtures were incubated for $1 \mathrm{~h}$ at room temperature and the absorbance of the supernatant was measured at $640 \mathrm{~nm}$, using a UV-Vis Lambda 25 spectrophotometer (Perkin Elmer Inc., Waltham, MA, USA). Finally, absorbance values were converted to carbohydrate concentration (mg/L) using glucose $(50 \mathrm{mg} / \mathrm{mL}$; Sigma-Aldrich, St. Louis, $\mathrm{MO}, \mathrm{USA}$ ) as a standard [27]. Carbohydrate concentration was expressed as $\mu \mathrm{g} / \mathrm{mg}$ protein. Data were reported as the mean value \pm standard deviation (S.D.) of three replicates $(n=3)$.

\subsection{Statistical Analysis}

Statistical analyses were performed using the SigmaStat 3.5 program (Systat Software Inc., San Jose, CA, USA). The ANOVA test was used to compare data between groups (i.e., control and Cd-treated samples). Tukey's honest significant difference (HSD) post-hoc test was applied when the differences in the measured values between groups were different $(p<0.05)$.

\section{Results}

\subsection{Cd Removal Efficiency}

The capacity of free-living Oscillatoria sp. to remove Cd from artificially-contaminated aqueous samples is shown in Figure 1. As can be appraised, $\mathrm{Cd}$ concentration from the medium (PBS, pH 7.4) decreased over time, and most of this reduction took place during the first $12-24 \mathrm{~h}$, at both tested metal concentrations (i.e., 5.0 and $25.0 \mathrm{mg} / \mathrm{mL}$ ). In addition, overall $\mathrm{Cd}$ removal performance by Oscillatoria sp. was negatively affected by the metal concentration increase. A maximal removal rate of $66.0 \%$ was reached when the cyanobacterial cells were exposed to $5.0 \mathrm{mg} / \mathrm{L}$ of $\mathrm{Cd}$ for $24 \mathrm{~h}$. However, at a metal concentration 5 times higher (i.e., $25.0 \mathrm{mg} / \mathrm{L})$, a slight decrease of around $7 \%(58.8 \%)$ was recorded in Cd removal from the aqueous system at the same period of time. These results suggest that Oscillatoria sp. might pose a series of biological mechanisms to deal with $\mathrm{Cd}$ intracellular toxicity.

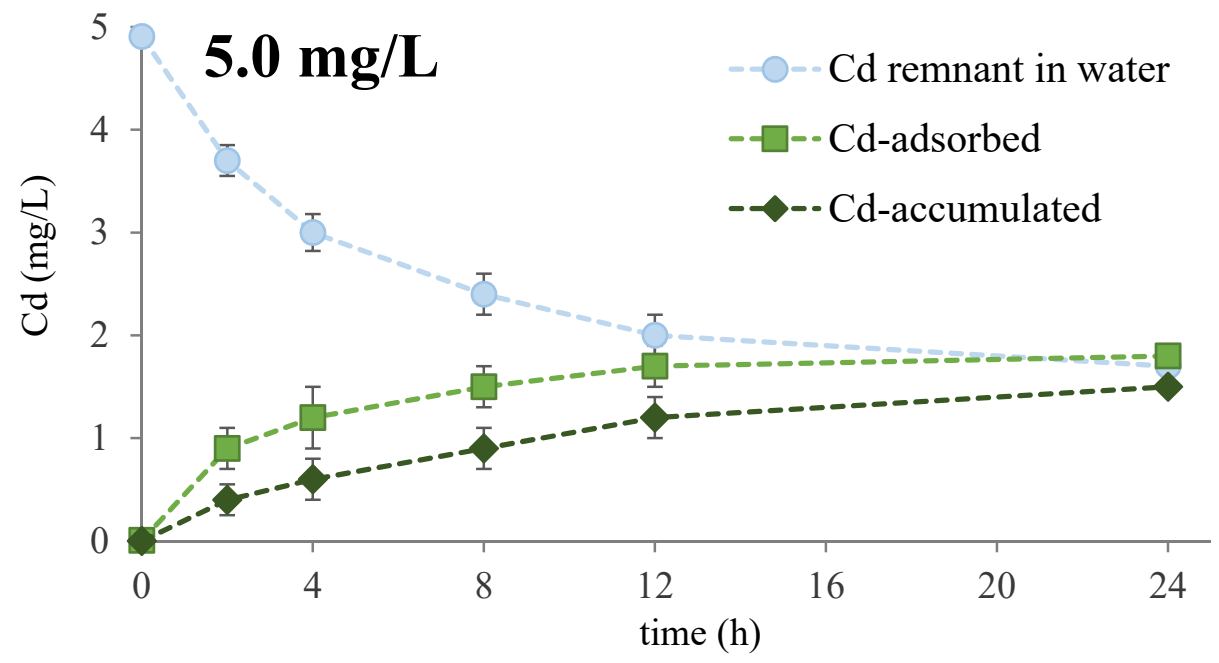

Figure 1. Cont. 


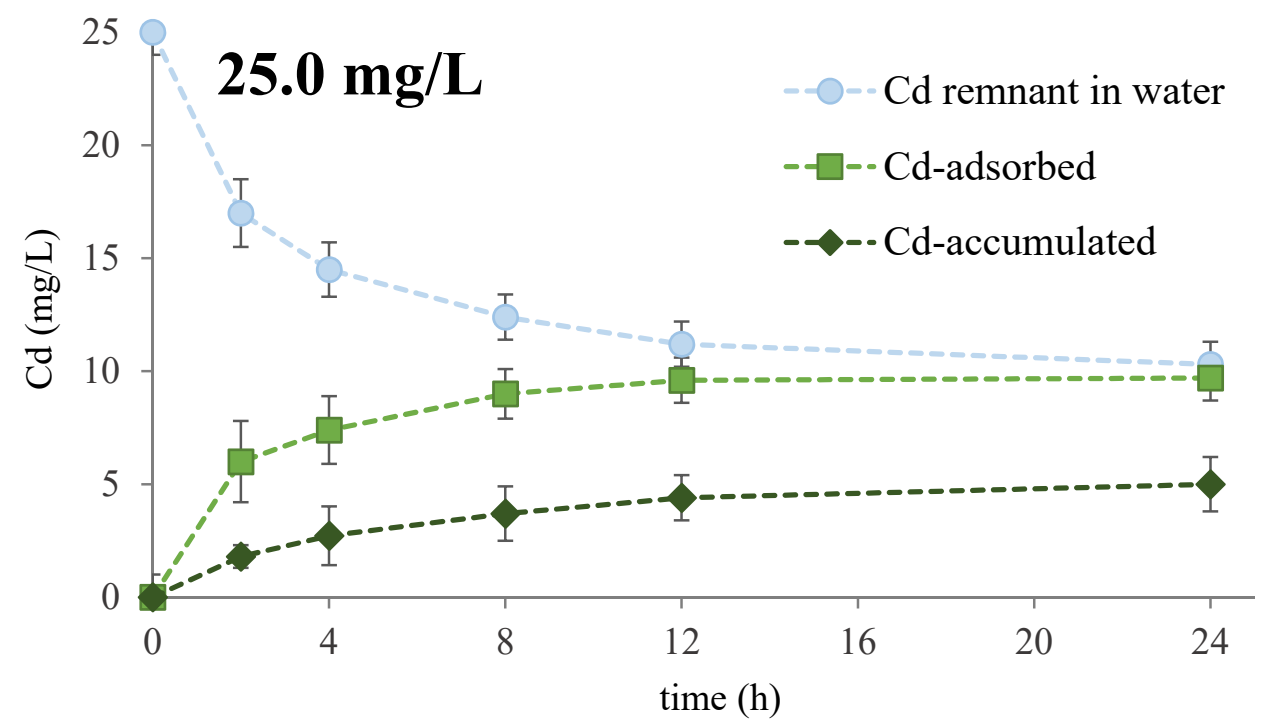

Figure 1. Metal removal $(\bullet)$, adsorption $(\mathbf{\square})$, and intracellular accumulation $(\bullet)$ kinetics in living Oscillatoria sp. during 24-h exposure at 5.0 or $25 \mathrm{mg} / \mathrm{L}$ of $\mathrm{Cd}$. Data are mean $\pm \mathrm{SD}$ of three independent experiments $(n=3)$.

Additionally, Cd removal from water fits a second-order reaction model (Table 1), suggesting that the entire bioprocess depends not only on the metal concentration, but also on the number/type of metal-binding sites in the microalgal biomass, among other potential metabolic features.

Table 1. First- and second-order kinetic parameters obtained for $\mathrm{Cd}$ removal by Oscillatoria sp.

\begin{tabular}{ccccc}
\hline \multirow{2}{*}{ Cd (mg/L) } & \multicolumn{2}{c}{ First-Order Kinetics } & \multicolumn{2}{c}{ Second-Order Kinetics } \\
\cline { 2 - 5 } & $\mathbf{K}_{\mathbf{1}} \mathbf{( 1 / h )}$ & $\mathbf{R}^{\mathbf{2}}$ & $\mathbf{K}_{\mathbf{2}} \mathbf{( L / m g ~ h )}$ & $\mathbf{R}^{\mathbf{2}}$ \\
\hline 5.0 & 0.0712 & 0.9237 & 0.0242 & 0.9981 \\
25.0 & 0.0597 & 0.8329 & 0.0038 & 0.9815 \\
\hline
\end{tabular}

In fact, a biphasic nature of $\mathrm{Cd}$ elimination can be clearly observed in Figure 1, with an initial rapid phase that occurs in the first $4 \mathrm{~h}$, and a slower one from $6 \mathrm{~h}$ onwards that reaches a plateau between 12-24 h of metal exposure. This non-linear $\mathrm{Cd}$ removal kinetics could be explained by the fact that living Oscillatoria sp. utilizes two principal mechanisms for metal elimination. The fastest component of metal uptake is $\mathrm{Cd}$ adsorption on the cyanobacterial cell outer membrane, while the second most important mechanism for $\mathrm{Cd}$ removal is metal accumulation within the cells (Figure 1). Moreover, the amount of accumulated $\mathrm{Cd}$ increased with time and was higher as the initial concentration of metal in the sample increased, suggesting the existence of some metabolic or physiological responses in Oscillatoria sp. that depends on the metal concentration, and to a lesser extent, on the time of exposure to the toxic metal.

In general, metal accumulation in living organisms involves a series of complex biologically-regulated processes, such as metal translocation by transmembrane proteins (e.g., porins) and ionic channels, and the posterior interaction with cysteine- and glutamic acid-rich peptides, such as glutathione, phytochelatins, and metallothioneins [19,36]. These peptides are able to form stable metal-protein complexes, thus reducing the deleterious effect of toxic metal ions on living cells [37]. The occurrence of metallothioneins and their importance for heavy metal detoxification were reported in several organisms including plants, yeast, bacteria, mollusks, cyanobacteria, and mammals [38]. In cyanobacteria, metallothioneins were first identified in cells adapted to grow in elevated levels of $\mathrm{Cd}$ or Zn [19]. Moreover, [39] reported the Cd-induced expression of a novel metallothionein (BmtA) in Oscillatoria brevis and its importance for metal detoxification. In addition, these 
authors suggested that $O$. brevis utilizes metallothionein as a primary heavy metal resistance mechanism to confer $\mathrm{Cd}$ tolerance to cells. A similar response might be used by other Oscillatoria species to deal with heavy metal toxicity; however, more experimental evidence is needed to support this hypothesis.

Our results showed that an increase in $\mathrm{Cd}$ accumulation was detected when metal concentration increased from 5.0 to $25.0 \mathrm{mg} / \mathrm{L}$, suggesting the induction of some response mechanisms (e.g., synthesis of metallothioneins, increased metal-storage/retention in vacuoles, etc.) involved in Cd bioaccumulation by Oscillatoria sp. However, the proportion of metal adsorbed was always higher than the amount of metal accumulated.

It was described that metal adsorption to cyanobacterial biomass occurs by a number of different physico-chemical interactions involving ionic bonds, cationic exchange, and chemical chelation. The presence of polysaccharides, proteins, and lipids on the surface of their cell walls containing different functional groups such as amino, hydroxyl, carboxyl, sulfate, and phosphate might act as binding sites for cationic metals [30]. In addition, the presence of negative charges (e.g., uronic acids) in cyanobacterial exopolysaccharides was proposed to play an important role in the sequestration of cations, a phenomenon of major interest for metallurgical industry wastewater treatment [19]. Therefore, a change in the functional groups of Oscillatoria sp. surface is a key point to understanding the metal binding mechanism in these photoautotrophic microorganisms.

In this study, functional groups on the surface of the cyanobacterial biomass responsible for $\mathrm{Cd}$ adsorption were determined by using FTIR-ATR spectroscopy, with and without Cd exposure. As can be appraised in Figure 2, several major bands at 3260, 2928, 1730, 1628, $1510,1450,1387,1231,1146$, and $1026 \mathrm{~cm}^{-1}$ were observed in the spectrum of non-treated Oscillatoria sp. biomass.

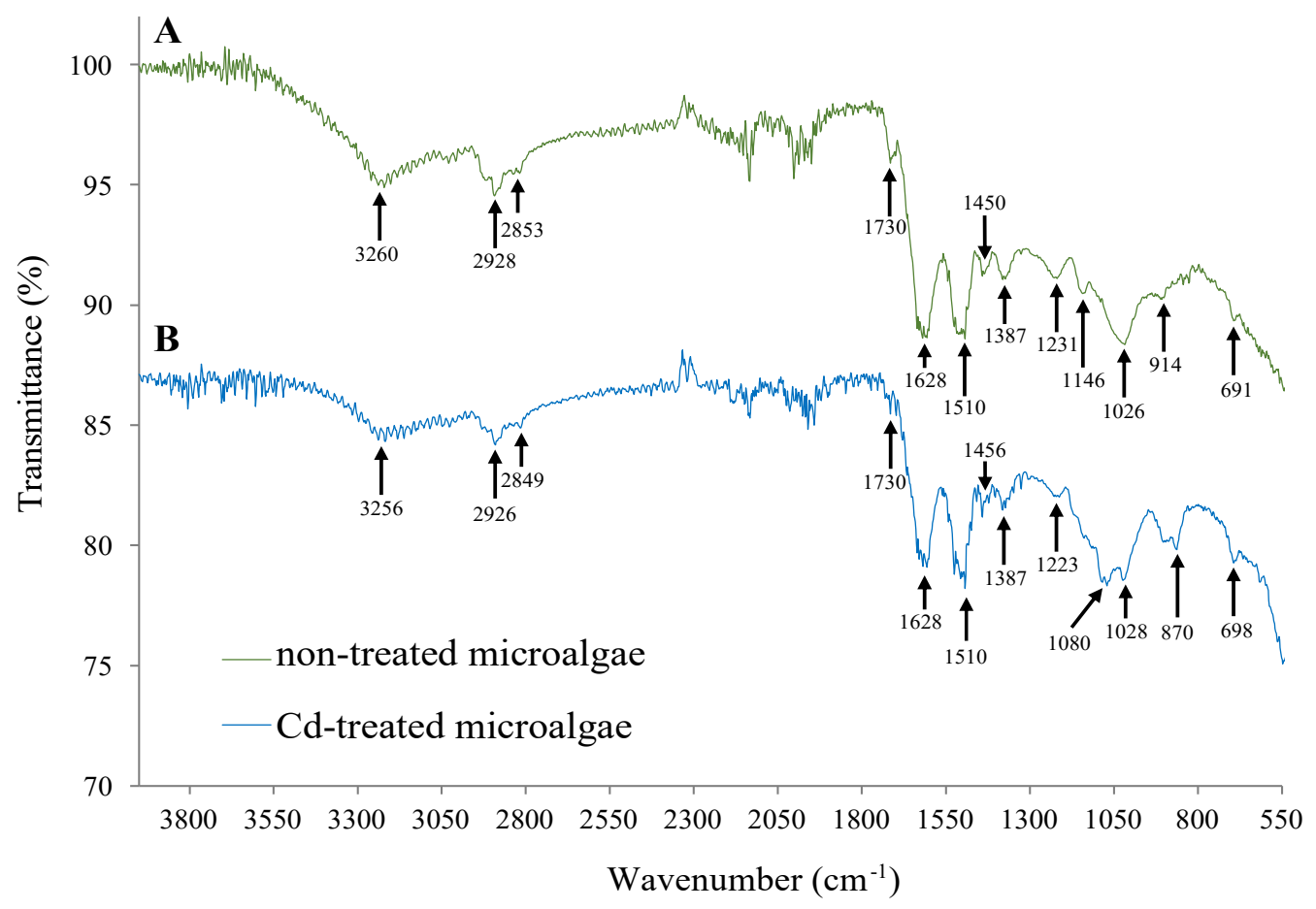

Figure 2. FTIR-ATR spectra of Oscillatoria sp. grown under control conditions (A) or after 24-h Cd exposure (B).

The broad band at $3500-3050 \mathrm{~cm}^{-1}$ was characteristic of the $\mathrm{O}-\mathrm{H}$ and $\mathrm{N}-\mathrm{H}$ groups [30], whereas the bands at 2928 and $2853 \mathrm{~cm}^{-1}$ refer to the asymmetric and symmetric vibration of methylene $\left(\mathrm{CH}_{2}\right)$, respectively [28]. The peaks at $1730 \mathrm{~cm}^{-1}$ correspond to the $\mathrm{C}=\mathrm{O}$ bond. The bands within the region of $1500-1000 \mathrm{~cm}^{-1}$ were characteristic of the ester group. Several peaks were obtained in this region, indicating the stretching vibrations. Other bands of the spectrum could be attributed as follows: $1628 \mathrm{~cm}^{-1}\left(-\mathrm{NH}_{2}\right.$ group or 
-C-N of amide), $1510 \mathrm{~cm}^{-1}$ (-N-H bending), $1387 \mathrm{~cm}^{-1}$ (- $\mathrm{CH}_{3}$ stretching), $1231 \mathrm{~cm}^{-1}\left(\mathrm{NO}_{2}\right.$ antisymmetric stretch), $1146 \mathrm{~cm}^{-1}$ (-C-O stretching of carboxylic acids), and $1026 \mathrm{~cm}^{-1}$ (-C-N and $-\mathrm{C}-\mathrm{C}$ stretching vibrations) [40]. The bands $<930 \mathrm{~cm}^{-1}$ are the fingerprint zone and include phosphate and sulfur functional groups [28].

Remarkable differences were observed in the spectra of Oscillatoria biomass obtained with and without $\mathrm{Cd}$ treatment (Figure 2). Many peaks in the spectrum of untreated cyanobacterial biomass shifted due to the presence of $\mathrm{Cd}$ in the medium. The shifting of peaks indicates that Oscillatoria sp. possess a metal binding ability, indicating the usefulness of this microalgae for treating Cd-containing effluents. In addition, some other bands showed a lower intensity because of the presence of the metal. These changes could be due to the $\mathrm{Cd}$ removal by the filamentous microalgae. Therefore, our results proved that different functional groups (mainly anionic ones) present at Oscillatoria sp. biomass such as carboxyl, phosphate, amide, amino, hydroxyl, sulfur, and others play a significant role in $\mathrm{Cd}$ adsorption. These results were consistent with related studies on the exposure of different microalgae to toxic metals [30,40].

Recently, [41] characterized the functional groups potentially involved in divalent copper ions $\left(\mathrm{Cu}^{2+}\right)$ adsorption on dried algae biomass of Oscillatoria splendida, by using FTIR spectroscopy. These authors described the presence of carbonyl, hydroxyl, and aliphatic chains acting as ligands for $\mathrm{Cu}$ binding. In the present study, the FTIR-ATR spectra obtained for Oscillatoria sp. biomass (Figure 2) with and without Cd-exposure were closely related to that reported by [41], suggesting that the high content of carbohydrates and lipids with negatively charged groups (mainly carboxyl and phosphate) present in the cyanobacterial biomass was the most relevant factor in determining $\mathrm{Cd}$ binding.

Related to this, [15] reported that $\mathrm{Cd}$ biosorption was maximal at a $\mathrm{pH}$ near neutrality, due to an increase in the number of negatively-charged ligands, which favored the binding of cationic metals, such as carboxyl and phosphate groups of lipopolysaccharides and phospholipids that were present in the outer membrane of Oscillatoria. Moreover, at more alkaline $\mathrm{pH}$ values (e.g., $\mathrm{pH}>8$ ), Cd solubility could be lowered due to the formation of metal hydroxides. On the other hand, in acidic conditions $(\mathrm{pH}<5)$, carboxyl and phosphate groups were closely linked to $\mathrm{H}^{+}$ions, thereby making these sites unavailable for $\mathrm{Cd}$ cations. Therefore, in order to ensure an active biological uptake by the free-living microalgae, media $\mathrm{pH}$ regulation is another important parameter to be considered since it not only affects cell viability and acid-base behavior of the metal binding sites, but also metal chemistry and bioavailability.

As mentioned before, the efficiency of Cd elimination by Oscillatoria sp. was negatively affected by the increase in Cd concentration from 5.0 to $25.0 \mathrm{mg} / \mathrm{L}$. However, it is worth noting that at higher Cd levels of $50 \mathrm{mg} / \mathrm{L}$, a greater metal removal efficiency was evidenced ( $>99 \%$ ), probably due to an increasing cell damage (data not shown). This fact could be associated with the exposure of additional metal-binding sites that enhanced $\mathrm{Cd}$ biosorption properties of the dead biomass, since non-living cells proved to be more efficient than living ones for metal elimination [15]. However, when microalgae were used as biosorbents (i.e., dead or inactive biomass) for removing metal ions, their low growth rates and cell densities made the biomass production very costly to be further used as inactive biomass for wastewater treatment. In contrast, the removal of metal ions by live microalgae cultures could overcome this disadvantage. In addition, a bioremediation of some nutritional components that frequently contributed to the eutrophication of aquatic ecosystems always occurred simultaneously during microalgae cultures [42].

Finally, one of the major hurdles in the removal of heavy metals by microalgae cultures is the high cost associated with the harvest of tiny cells from diluted cultures. A costeffective strategy for removing microbial cells from diluted broth is gravity sedimentation facilitated by flocculation, particularly by the self-flocculation properties of some microbial species. Thus, compared to other regular cyanobacteria species, flocculating Oscillatoria $\mathrm{sp}$. presents as an excellent candidate to be further explored for improved heavy metal 
tolerance, with the aim of applying it in metal-polluted wastewater management, due to the cost-effective sedimentation of these self-flocculating microorganisms.

\subsection{Evaluation of $\mathrm{Cd}$ Toxicity in Oscillatoria sp.}

Cyanobacteria are frequently challenged by toxic metals that have no function as nutrients. Due to their photoautotrophic lifestyle, cyanobacteria evolved to deal with toxic reactive oxygen species (ROS) produced by their metal-rich photosynthetic apparatus [19]. In the present study, Oscillatoria sp. showed different metabolic and physiological responses to $\mathrm{Cd}$ challenge. As can be seen in Table 2, Cd toxicity in Oscillatoria sp. live cells involves the generation of ROS, as shown by the increment in the levels of malondialdehyde (MDA). After 24-h of metal exposure, the content of MDA significantly increased by about $15 \%$ $(p<0.05)$ when the cells were treated with $5.0 \mathrm{mg} / \mathrm{mL}$ of $\mathrm{Cd}$, in comparison to the control untreated group, and up to $28 \%(p<0.05)$ with the highest tested metal concentration of $25.0 \mathrm{mg} / \mathrm{mL}$. These results might be explained by the increase in $\mathrm{Cd}$ bioaccumulation by microalgae, showed in Figure 1.

Table 2. Dehydrogenase activity; and concentrations of malondialdehyde (MDA), total protein, photosynthetic pigments, and soluble carbohydrates in Oscillatoria sp. cells after 24-h Cd exposure.

\begin{tabular}{cccc}
\hline \multirow{2}{*}{ Parameters } & \multicolumn{3}{c}{ Cd (mg/L) } \\
\cline { 2 - 4 } & $\mathbf{0 . 0}$ (Control) & $\mathbf{5 . 0}$ & $\mathbf{2 5 . 0}$ \\
\hline MDA content $(\mu \mathrm{mol} / \mathrm{mg})$ & $7.35 \pm 0.31^{\mathrm{a}}$ & $8.42 \pm 0.16^{\mathrm{b}}$ & $9.41 \pm 0.04^{\mathrm{c}}$ \\
DHase activity $(\mathrm{UA} / \mathrm{mg})$ & $17.7 \pm 0.1^{\mathrm{a}}$ & $14.6 \pm 0.1^{\mathrm{b}}$ & $14.4 \pm 0.4^{\mathrm{b}}$ \\
Cell density $(\mathrm{O} . \mathrm{D} \cdot 560 \mathrm{~nm})$ & $0.567 \pm 0.023^{\mathrm{a}}$ & $0.558 \pm 0.027^{\mathrm{a}}$ & $0.528 \pm 0.040^{\mathrm{a}}$ \\
Total proteins $(\mathrm{mg} / \mathrm{L})$ & $118.9 \pm 6.7^{\mathrm{a}}$ & $118.0 \pm 10.0^{\mathrm{a}}$ & $113.8 \pm 6.5^{\mathrm{a}}$ \\
chl- $\mathrm{a}(\mu \mathrm{g} / \mathrm{mg})$ & $53.6 \pm 3.6^{\mathrm{a}}$ & $53.7 \pm 1.7^{\mathrm{a}}$ & $51.2 \pm 3.4^{\mathrm{a}}$ \\
Carotenoids $(\mu \mathrm{g} / \mathrm{mg})$ & $139.3 \pm 7^{\mathrm{a}}$ & $119.8 \pm 2.1^{\mathrm{b}}$ & $117.6 \pm 6.0^{\mathrm{b}}$ \\
Carbohydrates $(\mu \mathrm{g} / \mathrm{mg})$ & $710 \pm 85^{\mathrm{a}}$ & $879 \pm 36^{\mathrm{b}}$ & $909 \pm 21^{\mathrm{b}}$ \\
\hline
\end{tabular}

MDA, malondialdehyde; DHAse, dehydrogenases. Results are presented as mean \pm S.D. $(n=3)$. Different lowercase letters in the same row represent significant statistical difference $(p<0.05)$ between metal concentration (e.g., "a" and "b" are statistically different from each other).

Metal toxicity is based on its chemical properties, and in general, promotes the production of ROS, the inactivation of enzymes, or the displacement of the normal metal cofactors in some cyanobacterial metalloproteins [19]. It was described that $\mathrm{Cd}$ ions are able to induce oxidative stress at similar doses to the ones used in the present study in related microorganisms, such as Chlorella vulgaris, Chlamydomonas reinhardtii, and Spirogyra setiformis $[40,43,44]$. Our results agreed with these observations; however, to the best of our knowledge, this was the first description of the Cd-induced oxidative stress in free-living Oscillatoria sp. cells.

The MDA content is considered an index of lipid peroxidation and a high level of MDA accumulation from peroxidation of unsaturated fatty acids can cause serious damage on nucleic acids and proteins [32]. In addition, ROS reaction with lipids and proteins might cause membrane damage, biomolecule degradation, and enzyme inactivation [19]. In fact, a decrease $(\sim 18 \%, p<0.05)$ in dehydrogenase (DHase) activity was detected in Oscillatoria sp. cells exposed to $\mathrm{Cd}$, with respect to the untreated control cells, after a 24-h metal exposure (Table 2). The reduction of tetrazolium salts, such as TTC, to redcolored formazan through degradative dehydrogenases, is a widely accepted method for detecting the physiological state of several organisms, including microalgae cultures [33,45]. Further, as TTC is a metabolic dye, suboptimal growth or stressful conditions (e.g., nutrient limitation, toxicant presence, etc.) could lead to inefficient TTC reduction by cells [46]. Therefore, the quantity of intracellular formazan product, estimated by its absorbance at $485 \mathrm{~nm}$, could be used as a surrogate marker of pollutant cytotoxicity [47]. Hence, the results shown in Table 2 suggest that Oscillatoria sp. is partially affected by $\mathrm{Cd}$ exposure and this might be related to metal-induced oxidative damage. 
However, it is noteworthy that cyanobacterial DHase activity decreased to a similar extent when Oscillatoria sp. was treated with $5.0 \mathrm{mg} / \mathrm{L}$ of $\mathrm{Cd}$ or with a metal concentration 5 times higher (i.e., $25.0 \mathrm{mg} / \mathrm{L}$ ). In addition, no changes in cellular density (O.D.560nm), protein content, and chlorophyll $a$ (chl-a) concentration were observed after 24-h metal exposure between control cells and Cd-treated cyanobacteria (Table 2). These results strongly suggest that Oscillatoria sp. might develop different enzymatic and non-enzymatic intracellular antioxidant responses to depress the oxidative stress induced by the metal. Additionally, it is important to mention that cellular reduction of tetrazolium compounds might proceed independent of ATP production [45], thus the observed decrease in the DHAse activity in Oscillatoria sp. is not necessarily related to an ATP depletion in the cells. However, as DHase activity is also related to cell viability, it should be appropriate to further evaluate cyanobacteria growth after long-term $\mathrm{Cd}$ exposure.

As mentioned before, Oscillatoria sp. seems to trigger some intracellular strategies to deal with Cd-induced oxidative damage. As can be appraised in Table 2, Cd exposure in Oscillatoria sp. interferes with the normal metabolism of carotenoids, since a significant reduction $(\sim 15 \%, p<0.05)$ in the total carotenoid content was observed in culture cyanobacteria exposed to $5.0 \mathrm{mg} / \mathrm{L}$ or $25.0 \mathrm{mg} / \mathrm{L}$ of $\mathrm{Cd}$ for $24 \mathrm{~h}$. Carotenoids are known to play important roles as antioxidants and accessory light-harvesting pigments. These compounds are essential to photosynthesis, acting as secondary pigments. They are also pro-vitamin factors, and are involved in free radical elimination [48]. Reactive oxygen species (ROS) can oxidize carotenoids, leading to a variety of oxidized products, including aldehydes, ketones, endoperoxides, and lactones. Some of these are reactive electrophile species that are bioactive and can induce changes in the gene expression, leading to acclimation of cells to stress conditions [49]. Furthermore, carotenoids quench excess excitation energy to protect chlorophyll molecules (the main pigments responsible for collecting solar radiation during the photosynthetic process) from oxidative damage preserving the ATP levels [50]. Therefore, our results suggest that Oscillatoria sp. might improve its antioxidative defense system under the metal stressful conditions through a carotenoid-mediated ROS quenching. Related to this, it is noteworthy that the chl-a content between the control and Cd-treated Oscillatoria sp. cells did not statistically change, probably due to a faster hydrolysis of carotenoids, compared to chl-a in the cells under metallic stress (Table 2).

Moreover, the cyanobacteria culture did not show a marked reduction of their cell density (as a surrogate marker of biomass growth) and total protein content, as compared to the control group, after a 24-h metal exposure (Table 2). In this context, [42] recently proposed that the formation of photosynthetic pigments, in particular chl-a, synchronized with the growth of the microalgal cells, could be used as an indicator for evaluating the removal efficiency of metal ions from polluted water.

Besides its impact on cyanobacterial oxidative stress, DHAse activity, and carotenoid content, $\mathrm{Cd}$ exposure also affected carbohydrate production by the filamentous microalgae. As shown in Table 2, the content of soluble carbohydrates in Oscillatoria sp. significantly increased $(p<0.05)$ at both tested metal concentrations (i.e., 5.0 and $25.0 \mathrm{mg} / \mathrm{L}$ ). These results might be explained by a reduction in carbohydrate utilization as a consequence of a lower rate in carbon assimilation caused by the reduction in the total carotenoid content. Further, the environmental stressful conditions caused by $\mathrm{Cd}$ exposure could induce the mobilization of soluble sugars where required, in order to preserve the osmotic homeostasis of the cyanobacterial cells, since these compounds not only act as structural cellular constituents, but also as intracellular signaling molecules involved in the regulation of metabolic processes associated with growth, ATP production, and survival of cells. Therefore, it is possible that the stress caused in Oscillatoria sp. due to the intracellular accumulation of $\mathrm{Cd}$ prompts an increase in the amount of soluble carbohydrates as a protective mechanism, in order to counteract the oxidative damage, since these biomolecules play a very active role in cell energy management. A similar behavior was reported in plants exposed to heavy metal stress [51-53], thus, it is possible that a similar mechanism could be used by photosynthetic microalgae. 
Collectively, these data suggest that Cd-challenged Oscillatoria sp. might trigger an integrated reprogramming of their carotenoid and carbohydrate metabolism to protect, on one hand, the photosynthesis (i.e., preserve $c h l-a$ content), which normally provides ATP for cell growth and viability, and on the other hand, the protein synthesis, limiting in this way the poisoning incorporation of $\mathrm{Cd}$ into cells. Therefore, the tolerance of a cyanobacterium against heavy metal stress seems to be controlled by a complex and highly interrelated network of molecular and physiological approaches that help to counteract metal phytotoxicity. However, more evidence in Oscillatoria sp. is still needed at the molecular level (e.g., up- and down-regulation of genes), in order to understand these fascinating mechanisms. Additionally, large-scale performance assays and long-term metal removal studies using free-living cells are still needed to further design microalgae-based systems for industrial-scale wastewater management.

\section{Conclusions}

New insights on Cd removal by free-living Oscillatoria sp. was presented. FTIRATR spectroscopy revealed that distinct functional groups present at the surface of the cyanobacterial cell walls play a significant role on metal adsorption. However, Oscillatoria also showed a great potential for the bioaccumulation of $\mathrm{Cd}$, suggesting the induction of some intracellular strategies to deal with $\mathrm{Cd}$ toxicity. Additionally, $\mathrm{Cd}$ bioaccumulation induced cell oxidative damage and harmed cyanobacterial metabolic activities, under the metal-stressful conditions. However, Oscillatoria sp. proved to be able to early trigger some defense mechanisms against the $\mathrm{Cd}$-induced oxidative damage, such as ROS quenching by carotenoids and the increase in carbohydrates catabolism (e.g., glycogen degradation), in order to maintain an active photosynthetic and energetic machinery. Notably, no impact of $\mathrm{Cd}$ toxicity on cell growth, chlorophyll- $a$ content, and total protein of microalgae was observed after 24-h metal exposure, even at the highest metal concentration tested (i.e., $25.0 \mathrm{mg} / \mathrm{L}$ ). Therefore, our study opens the possibility of finding an equilibrium that maximizes metal removal performance with an active cyanobacterial metabolism. Hence, additional studies are needed in order to efficiently couple $\mathrm{Cd}$ bioremediation with Oscillatoria biomass growth, so as to exploit the fully metabolic potential of these photosynthetic microorganisms, aiming to achieve a rewarding and more sustainable management of industrial metal-polluted wastewater.

Author Contributions: Conceptualization, L.M.S. and L.M.P.; methodology, I.C.B. and L.D.L.; formal analysis, I.C.B. and L.M.P.; investigation, I.C.B. and L.D.L.; writing-original draft preparation, L.M.P.; writing — review and editing, L.M.S., J.M., and L.M.P.; supervision, L.M.S. and L.M.P.; project administration, L.M.S. and L.M.P.; funding acquisition, L.M.S. and L.M.P. All authors have read and agreed to the published version of the manuscript.

Funding: This research was funded by Agencia Nacional de Promoción Científica y Tecnológica (ANPCyT, Ministerio de Ciencia, Tecnología e Innovación, Argentina) and the Pontifical Catholic University of Argentina (UCA), grant number PICTO-2017-0060.

Acknowledgments: The authors want to thank Lic. Esp. Luciano Méndez from the National Institute of Agricultural Technology (INTA-Rosario, Centro Regional Santa Fe, Argentina) for providing us with the Oscillatoria sp. inoculum. We also want to thank Lic. C. Daniela Bergara (Fac. de Química e Ingeniería, UCA-campus Rosario) for her technical advice. I.C.B. wishes to thank the National Council for Scientific and Technical Research (CONICET, Argentina) for the funds provided. Finally, the authors would like to thank Luisina Torrá (Mat. 1132, Association of Translators of the Province of Santa Fe, 2nd District) for her technical assistance during language proofreading.

Conflicts of Interest: The authors declare no conflict of interest. The funders had no role in the design of the study; in the collection, analyses, or interpretation of data; in the writing of the manuscript, or in the decision to publish the results. 


\section{References}

1. Wu, X.; Cobbina, S.J.; Mao, G.; Xu, H.; Zhang, Z.; Yang, L. A review of toxicity and mechanisms of individual and mixtures of heavy metals in the environment. Environ. Sci. Pollut. Res. 2016, 23, 8244-8259. [CrossRef]

2. Anyanwu, B.O.; Ezejiofor, A.N.; Igweze, Z.N.; Orisakwe, O.E. Heavy metal mixture exposure and effects in developing nations: An update. Toxics 2018, 6, 65. [CrossRef]

3. Idrees, N.; Tabassum, B.; Abd Allah, E.F.; Hashem, A.; Sarah, R.; Hashim, M. Groundwater contamination with cadmium concentrations in some West U.P. Regions, India. Saudi J. Biol. Sci. 2018, 25, 1365-1368. [CrossRef] [PubMed]

4. Hayat, M.T.; Nauman, M.; Nazir, N.; Ali, S.; Bangash, N. Environmental hazards of cadmium: Past, present, and future. In Cadmium Toxicity and Tolerance in Plants: Agronomic, Genetic, Molecular and Omic Approaches, 1st ed.; Hasanuzzaman, M., Prasad, M.N.V., Fujita, M., Eds.; Academic Press: Cambridge, MA, USA, 2019; pp. 163-183. [CrossRef]

5. Chunhabundit, R. Cadmium exposure and potential health risk from foods in contaminated area, Thailand. Toxicol. Res. 2016, 32, 65-72. [CrossRef] [PubMed]

6. Rahimzadeh, M.R.; Kazemi, S.; Moghadamnia, A.A. Cadmium toxicity and treatment: An update. Caspian J. Intern. Med. 2017, 8, 135-145. [CrossRef]

7. Qu, R.J.; Wang, X.H.; Feng, M.B.; Li, Y.; Liu, H.X.; Wang, L.S.; Wang, Z.Y. The toxicity of cadmium to three aquatic organisms (Photobacterium phosphoreum, Daphnia magna and Carassius auratus) under different pH levels. Ecotox. Environ. Saf. 2013, 95, 83-90. [CrossRef] [PubMed]

8. Zaki, M.S.; Zakaria, A.; Eissa, I.A.; Eldeen, A.I. Effect of cadmium toxicity on Vertebrates. Electron. Physician 2016, 8, 1964-1965. [CrossRef]

9. WHO. Chemical Safety-Activity Report; World Health Organization: Geneva, Switzerland, 2017.

10. Azimi, A.; Azari, A.; Rezakazemi, M.; Ansarpour, M. Removal of heavy metals from industrial wastewaters: A review. ChemBioEng. Rev. 2017, 4, 37-59. [CrossRef]

11. Barakat, M.A. New trends in removing heavy metals from industrial wastewater. Arab. J. Chem. 2011, 4, 361-377. [CrossRef]

12. Azubuike, C.C.; Chikere, C.B.; Okpokwasili, G.C. Bioremediation techniques-classification based on site of application: Principles, advantages, limitations and prospects. World J. Microbiol. Biotechnol. 2016, 32, 180-198. [CrossRef]

13. Dhir, B. Potential of biological materials for, removing heavy metals from wastewater. Environ. Sci. Pollut. Res. 2014, 21, 1614-1627. [CrossRef]

14. Dixit, R.; Wasiullah; Malaviya, D.; Pandiyan, K.; Singh, U.B.; Sahu, A.; Shukla, R.; Singh, B.P.; Rai, J.P.; Sharma, P.K.; et al. Bioremediation of heavy metals from soil and aquatic environment: An overview of principles and criteria of fundamental processes. Sustainability 2015, 7, 2189-2212. [CrossRef]

15. Azizi, S.N.; Colagar, A.H.; Hafeziyan, S.M. Removal of Cd(II) from aquatic system using Oscillatoria sp. biosorbent. Sci. World J. 2012, 1-7. [CrossRef]

16. Katircioğlu, H.; Aslim, B.; Rehber Türker, A.; Atici, T.; Beyatli, Y. Removal of cadmium(II) ion from aqueous system by dry biomass, immobilized live and heat-inactivated Oscillatoria sp. H1 isolated from freshwater (Mogan Lake). Bioresour. Technol. 2008, 99, 4185-4191. [CrossRef]

17. Rao, K.S.; Mohapatra, M.; Anand, S.; Venkateswarlu, P. Review on cadmium removal from aqueous solutions. Int. J. Eng. Sci. Technol. 2010, 2, 81-103. [CrossRef]

18. Satya, A.; Harimawan, A.; Haryani, G.S.; Johir, M.A.H.; Vigneswaran, S.; Ngo, H.H.; Setiadi, T. Batch study of cadmium biosorption by carbon dioxide enriched Aphanothece sp. dried biomass. Water 2020, 12, 264. [CrossRef]

19. Cassier-Chauvat, C.; Chauvat, F. Responses to oxidative and heavy metal stresses in cyanobacteria: Recent advances. Int. J. Mol. Sci. 2015, 16, 871-886. [CrossRef]

20. Singh, S. Biosorption of heavy metals by cyanobacteria: Potential of live and dead cells in bioremediation. In Microbial Bioremediation E Biodegradation; Shah, M., Ed.; Springer: Singapore, 2020; pp. 409-423. [CrossRef]

21. Riskuwa-Shehu, M.; Ismail, H.; Sulaiman, M. Biosorption of heavy metals by Oscillatoria species. Microbiol. Res. J. Int. 2019, 27, 1-8. [CrossRef]

22. Barkia, I.; Saari, N.; Manning, S.R. Microalgae for high-value products towards human health and nutrition. Mar. Drugs 2019, 17, 304. [CrossRef] [PubMed]

23. Sevda, S.; Garlapi, V.G.; Sharma, S.; Bhattacharya, S.; Mishra, S.; Sreekrishnan, T.R.; Pant, D. Microalgae at niches of bioelectrochemical systems: A new platform for sustainable energy production coupled industrial effluent treatment. Bioresour. Technol. Rep. 2019, 7, 100290. [CrossRef]

24. Zahra, Z.; Choo, D.H.; Lee, H.; Parveen, A. Cyanobacteria: Review of current potentials and applications. Environments 2020, 7, 13. [CrossRef]

25. Bejjanki, D.; Muthukumar, K.; Radhakrishnan, T.K.; Alagarsamy, A.; Pugazhendhi, A.; Mohamed, S.N. Simultaneous bioelectricity generation and water desalination using Oscillatoria sp. as biocatalyst in photosynthetic microbial desalination cell. Sci. Total. Environ. 2021, 754, 142215. [CrossRef] [PubMed]

26. Kokabian, B.; Gude, V.G. Photosynthetic microbial desalination cells (PMDCs) for clean energy, water and biomass production. Environ. Sci. Process. Impacts 2013, 15, 2178-2185. [CrossRef]

27. Emiliani, J.; Llatance Oyarce, W.G.; Bergara, C.D.; Salvatierra, L.M.; Novo, L.A.B.; Pérez, L.M. Variations in the phytoremediation efficiency of metal-polluted water with Salvinia biloba: Prospects and toxicological impacts. Water 2020, 12, 1737. [CrossRef] 
28. Tello Zevallos, W.; Salvatierra, L.M.; Loureiro, D.B.; Morató, J.; Pérez, L.M. Evaluation of the autochthonous free-floating macrophyte Salvinia biloba Raddi for use in the phytoremediation of water contaminated. Desalin. Water Treat. 2018, 103, 282-289. [CrossRef]

29. Zheng, X.; Bi, C.; Li, Z.; Podariu, M.; Hage, D.S. Analytical methods for kinetic studies of biological interactions: A review. J. Pharm. Biomed. Anal. 2015, 113, 163-180. [CrossRef] [PubMed]

30. Balaji, S.; Kalaivani, T.; Shalini, M.; Gopalakrishnan, M.; Muhammad, M.A.R.; Rajasekaran, C. Sorption sites of microalgae possess metal binding ability towards $\mathrm{Cr}(\mathrm{VI})$ from tannery effluents-A kinetic and characterization study. Desalin. Water Treat. 2016, 57, 14518-14529. [CrossRef]

31. Lowry, O.; Rosebroug, H.; Farr, A.; Randall, R. Protein measurement with the Folin-phenol reagent. J. Biol. Chem. 1951, 193, 265-275. [CrossRef]

32. Piotrowska-Niczyporuk, A.; Bajguz, A.; Zambrzycka, E.; Godlewska-Żyłkiewicz, B. Phytohormones as regulators of heavy metal biosorption and toxicity in green alga Chlorella vulgaris (Chlorophyceae). Plant Physiol. Biochem. 2012, 52, 52-65. [CrossRef]

33. Capasso, J.M.; Cossío, B.R.; Berl, T.; Rivard, C.J.; Jiménez, C. A colorimetric assay for determination of cell viability in algal cultures. Biomol. Eng. 2003, 20, 133-138. [CrossRef]

34. Miazek, K.; Ledakowicz, S. Chlorophyll extraction from leaves, needles and microalgae: A kinetic approach. Int. J. Agric. Biol. Eng. 2013, 6, 107-115. [CrossRef]

35. Dubois, M.; Gilles, K.; Hamilton, J.; Rebers, P.; Smith, F. Colorimetric method for determination of sugars and related substances. Anal. Chem. 1956, 28, 350-356. [CrossRef]

36. Hall, J.L. Cellular mechanisms for heavy metal detoxification and tolerance. J. Exp. Bot. 2002, 53, 1-11. [CrossRef] [PubMed]

37. Cobbett, C.; Goldsbrough, P. Phytochelatins and metallothioneins: Roles in heavy metal detoxification and homeostasis. Annu. Rev. Plant Biol. 2002, 53, 159-182. [CrossRef]

38. Ziller, A.; Fraissinet-Tachet, L. Metallothionein diversity and distribution in the tree of life: A multifunctional protein. Metallomics 2018, 10, 1549-1559. [CrossRef] [PubMed]

39. Liu, T.; Nakashima, S.; Hirose, K.; Uemura, Y.; Shibasaka, M.; Katsuhara, M.; Kasamo, K. A metallothionein and CPx-ATPase handle heavy-metal tolerance in the filamentous cyanobacterium Oscillatoria brevis 1. FEBS Lett. 2003, 542, 159-163. [CrossRef]

40. Çelekli, A.; Gültekin, E.; Bozkurt, H. Morphological and biochemical responses of Spirogyra setiformis exposed to Cadmium. Clean-Soil Air Water 2016, 44, 256-262. [CrossRef]

41. Mohadi, R.; Setiawan, D.; Zulkifli, H. Biosorption of $\mathrm{Cu}(\mathrm{II})$ onto algae biomass (Oscillatoria splendida) isolated from swamp water ecosystem in Palembang, South Sumatera. J. Phys. Conf. Ser. 2019, 1282, 012066. [CrossRef]

42. Alam, M.A.; Wan, C.; Zhao, X.Q.; Chen, L.J.; Chang, J.S.; Bai, F.W. Enhanced removal of $\mathrm{Zn}^{2+}$ or Cd ${ }^{2+}$ by the flocculating Chlorella vulgaris JSC-7. J. Hazard. Mater. 2015, 289, 38-45. [CrossRef] [PubMed]

43. Cheng, J.; Qiu, H.; Chang, Z.; Jiang, Z.; Yin, W. The effect of cadmium on the growth and antioxidant response for freshwater algae Chlorella vulgaris. SpringerPlus 2016, 5, 1290. [CrossRef] [PubMed]

44. Jamers, A.; Lenjou, M.; Deraedt, P.; Van Bockstaele, D.; Blust, R.; de Coen, W. Flow cytometric analysis of the cadmium-exposed green alga Chlamydomonas reinhardtii (Chlorophyceae). Eur. J. Phycol. 2009, 44, 541-550. [CrossRef]

45. Berridge, M.V.; Herst, P.M.; Tan, A.S. Tetrazolium dyes as tools in cell biology: New insights into their cellular reduction. Biotechnol. Annu. Rev. 2005, 11, 127-152. [CrossRef] [PubMed]

46. Ghaly, A.E.; Mahmoud, N. Optimum conditions for measuring dehydrogenase activity of Aspergillus niger using TTC. Am. J. Biochem. Biotechnol. 2006, 2, 186-194. [CrossRef]

47. Pérez, L.M.; López Álvarez, B.L.; Codony, F.; Fittipaldi, M.; Adrados, B.; Peñuela, G.; Morató, J. A new microtiter plate screening method for evaluating the viability of aerobic respiring bacteria in high surface biofilms. Lett. Appl. Microbiol. 2010, 51, 331-337. [CrossRef] [PubMed]

48. Hirschberg, J.; Chamovitz, D. Carotenoids in Cyanobacteria. In The Molecular Biology of Cyanobacteria. Advances in Photosynthesis; Bryant, D.A., Ed.; Springer: Dordrecht, The Netherlands, 1994; Volume 1, pp. 559-579. [CrossRef]

49. Havaux, M. Carotenoid oxidation products as stress signals in plants. Plant J. 2014, 79, 597-606. [CrossRef] [PubMed]

50. Ramel, F.; Mialoundama, A.S.; Havaux, M. Nom-enzymic carotenoid oxidation and photooxidative stress signaling in plants. J. Exp. Bot. 2013, 64, 799-805. [CrossRef]

51. Castillo Loría, K.; Emiliani, J.; Bergara, C.D.; Herrero, M.S.; Salvatierra, L.M.; Pérez, L.M. Effect of daily exposure to Pbcontaminated water on Salvinia biloba physiology and phytoremediation performance. Aquat. Toxicol. 2019, 210, 158-166. [CrossRef]

52. Prado, C.; Rodríguez-Montelongo, L.; González, J.A.; Pagano, E.A.; Hilal, M.; Prado, F.E. Uptake of chromium by Salvinia minima: Effect on plant growth, leaf respiration and carbohydrate metabolism. J. Hazard. Mater. 2010, 177, 546-553. [CrossRef] [PubMed]

53. Rosa, M.; Prado, C.; Podazza, G.; Interdonato, R.; González, A.; Prado, F. Soluble sugars-metabolism, sensing and abiotic stress. Plant Signal. Behav. 2009, 4, 388-393. [CrossRef] [PubMed] 